вживаної та професійно-спрямованої іншомовної комунікативної компетенції.

\title{
Література:
}

1. Концепція розвитку дистанційної освіти в Україні. (Затверджено Постановою МОН України від 20 грудня 2000 р.) [Електронний pecypc]: http://www.osvita.org.ua/distance/pravo/00.html

2. Белянина М.В. Дистанционное обучение иностранному языку в неязыковом вузе // Гуманитарное образование: история, традиции, перспективы: сборник научных трудов. Выпуск 3. Елец: ЕГУ им. И.А. Бунина, 2014. 77-82 с.

3. Шарифулина А.А. Языковые социальные сети в обучении английскому языку. [Електронний pecypc]: http://sci-article.ru/stat. php?i=1411295694

DOI https://doi.org/10.30525/978-9934-588-80-8-2.6

\section{DEVELOPING COMMUNICATION SKILLS OF STUDENTS OF HUMANITARIAN AND NATURAL SPECIALTIES AS A SOFT SKILL IN THE PROCESS OF TRAINING}

\author{
Zhukova O. A. \\ Doctor of Pedagogical Sciences, Associate Professor, \\ Head of Pedagogy Department \\ V. N. Karazin Kharkiv National University \\ Kharkiv, Ukraine
}

Trainings are one of the most spread forms of work with students. They are studied by modern scientists in broad and narrow meanings [16: p. 287]. Studying training in a broad sense allows us to evaluate it as a form of work with a groupto take into account external and internal factors, objective and subjective conditions in the process of interaction between the teacher and the participants [4]. If the researcher views training as a program of various systematically carried out actions to develop certain qualities, attitudes, abilities and skills [2: p.15; 13: p. 70], there is a need for studying it in a narrow perspective.

The narrow context of perception of this form of interaction in the formal and informal segments of the educational system makes it possible for the teacher as the organizer of the training to specify goal setting and, according to the taxonomy of B. Bloom's goals [19], to trace the correspondence of 
ideal goals to real results at the level of knowledge, understanding, application, analysis, synthesis, and evaluation.

The applied nature of this form of interaction indicates its ability to improve the behavioral patterns of students, to expand and to deepen knowledge they acquired during the learning process that will be in demand in their further life.

Currently teachers use various types of trainings of future specialists including trainings that help to develop social communication skills. Social communication is one of the important aspects in the life of an individual and society as a whole. Analysis of the works of its researchers $[1 ; 3 ; 5$; $8 ; 10]$ allows highlighting the following main functions: maintaining a variety of human relations with the outside world; obtaining and analyzing information; exchange of thoughts, ideas, impressions, emotions; enrichment of the inner world of an individual; transfer of the accumulated experience to the next generation. For this reason, communication skills are currently one of the most demanded features of an individual. These skills are also one of the basic cognitive skills of a person [20]. In this context, communication trainings are a part of teachers' functional activities aimed at developing such soft skills in students.

Communication trainings can be an independent form of acquiring and improving practical skills (e.g., basic communication training to stage various types of communication), as well as can be a part of other trainings (for example, leadership training, emotional intelligence training, team building training, etc.)

In the process of trainings with students of humanitarian and natural specialties, communication as one of the soft skills can be developed through both verbal [11] and non-verbal interaction which can be represented by non-linguistic symbols, signs, means for transmitting and perceiving information among its participants [18].

The researchers of this phenomenon [12] draw attention to the need to take into account its dependence on the social and psychological development of an individual: the external and internal factors, subjective and objective, social and the uniquely individual.

Using communication training as an independent form of developing respective skills in students of natural and humanitarian specialties requires a number of actions on the part of the teacher and the participants.

The analysis of information sources $[6 ; 7 ; 14 ; 15 ; 17]$ shows that the teacher's actions can be aimed at providing the students with the necessary information on the types of communication (mass, public, interpersonal), styles and tactics of verbal communication; features of business/formal and informal types of communication; communication in an intercultural 28 
environment, policy and components of intercultural interaction, rules and principles of dialogue in ethnic cultures and subcultures, possible ways to prevent conflict situations; typology of conflicts, their diagnosis, strategies for resolving conflicts in the process of communication.

In the process of developing students' communication skills, the organizer of the training group uses various techniques and methods aimed at deepening the following components [9, p. 176]: the cognitive one, based on the acquired knowledge and communication experience of the participants; the communicative and speech ones which assume the presence of listening skills, as well as clearly and eloquently expressing one's thoughts, using a certain tempo and tone of speech; the socio-perceptual one based on the ability to adequately receive and evaluate communicative interaction; the interactive one aimed at establishing contact and conducting polylogue in the communication process.

Actions of participants of trainings aimed at forming communication soft skills are directed towards comprehending received information and determining possible ways of applying it in real situations.

The basis for interaction between the teacher and the participants of the communication trainings are active and interactive teaching methods (games, cases, brain storming, synectic methods, and exercises of various degrees of difficulty).

Thus, the narrow context of the study of the training allows to consider it as one of the possible forms of developing students' communication skills, and as a basic cognitive skill. As a soft skill that has a supra-subject nature it is an integral part of the existence of a person and society and can be developed in the system of formal and informal segments of the educational system though special pedagogical forms and methods including training.

\section{References:}

1. Андерсон K. Успішні виступи на TED. Рецепти найкращих спікерів / пер. $з$ англ. О. Асташової. 2-ге вид. Київ: Наш формат, 2017. $256 \mathrm{c}$.

2. Бакли Р., Кейпл Дж. Теория и практика тренинга. СанктПетербург: Питер-Пресс, 1997. 256 с.

3. Білан Н. І. Соціальні комунікації в інформаційному суспільстві: теорія, еволюція, моделі та прикладні аспекти: дис. ... д-ра наук: із соц. комунікації: 27.00.01/ Київ. нац. ун-т імені Тараса Шевченка; Інститут журналістики. Київ, 2016. 427 с.

4. Вачков И.В. Основы технологии группового тренинга. Психотехники: учебное пособие. 3-е изд., перераб. и доп. Москва: Ось-89, 2007. $256 \mathrm{c}$. 
5. Власов П. К. Партнёрское общение. Тренинг. Игры и упражнения. Метод. материалы для ведущего; 2-е изд., испр., доп., перераб. Харьков: Гуманитарный центр, 2014. 172 с.

6. Голуб О. Ю., Тихонова С. В. Теория коммуникации: Учебник. Москва: Дашков и К, 2016. 388 с.

7. Гуревич Т. М. Национально-культурная обусловленность непрямой коммуникации. Вестник МГИМО-Университета. 2013. № 2 (29) C. 163-166.

8. Корніяка О. М. Особливості розвитку комунікативної компетентності фахівців на різних етапах їх професійного становлення. Психолінгвістика: зб. наук. праць ДВНЗ «Переяслав-Хмельницький державний педагогічний університет імені Григорія Сковороди». Переяслав-Хмельницький: ПП «СКД», 2011. Вип. 8. С. 33-45.

9. Лахтадир О. В. Психологічні особливості розвитку комунікативної компетентності майбутніх фахівців з фізичної культури і спорту: дис.канд.психол.наук: 19.00.07. Київ, Інститут Психології імені Г.С. Костюка, 2017. 261 с.

10. Мермани Э. Коммуникация и коммуникабельность. Практ. рекоменд. для открытой коммуникации. 2-е изд., испр. / пер. с нем. Е.И. Высочинова, А.В. Коченгин, Харків: Изд-во Гуманит Центр, 2015. $260 \mathrm{c}$.

11. Москвин В. П. Риторика и теория коммуникации: Виды, стили и тактики речевого общения Москва: КД Либроком, 2015. 218 с.

12. Орбан-Лембрик Л. Е. Психологія професійної комунікації: навч. посіб. Чернівці: Книги-XXI, 2010. 528 с.

13. Пугачев В. П. Тесты, деловые игры, тренинги в управлении персоналом. Москва: Аспект Пресс, 2002. 285 с.

14. Рот Ю., Коптельцева Г. Межкультурная коммуникация. Теория и тренинг. Учебно-методическое пособие. Москва: Юнити Дана, 2012. $224 \mathrm{c}$.

15. Садохин А. П. Введение в теорию межкультурной коммуникации: учебное пособие. Москва: КноРус, 2016. 256 с.

16. Сидоров В. Профессиональная деятельность социального работника: ролевой подход. Винница: «Глобус-пресс», 2006. 408 с.

17. Чамкин А. С. Основы коммуникологии (теория коммуникации): учебное пособие. Москва: НИЦ ИНФРА-М, 2013. 350 с.

18. Яшин Б. Л. Культура общения: теория и практика коммуникаций: учебное пособие. Москва: Директ-Медиа, 2015. 243 с.

19. Bloom B.S., Engelhart M.D., Furst E.J., Hill W.H., Krathwohl D. R. (1956). Taxonomy of educational objectives: The classification of 
educational goals. Handbook I: Cognitive domain. New York: David McKay Company.

20. MGI-Skill-Shift-Automation-and-future-of-the-workforce (2018). https://www.mckinsey.com/ /media/McKinsey/Industries/Public\%20and\%2 0Social\%20Sector/Our\%20Insights/Skill\%20shift\%20Automation\%20and\% 20the $\% 20$ future $\% 20 \mathrm{of} \% 20$ the $\% 20$ workforce/MGI-Skill-Shift-Automationand-future-of-the-workforce-In-brief-May-2018.pdf (accessed 10.09.20).

DOI https://doi.org/10.30525/978-9934-588-80-8-2.7

\title{
ОРГАНІЗАЦІЯ САМОСТІЙНОЇ ТА ІНДИВІДУАЛЬНОЇ РОБОТИ УЧНІВ В УМОВАХ ДИСТАНЦЙНОЇ ОСВІТИ
}

\author{
Задоріна О. М. \\ кандидат педагогічних наук, \\ стариий викладач кафедри методики викладання і змісту освіти \\ КЗ «Одеська академія неперервної освіти Одеської обласної ради»
}

Задорін В. В.

викладач інформатики

Одеський фаховий технічний коледж

Одеської національної академії харчових технологій

м. Одеса, Україна

Гуманізація освіти передбачає перегляд, переоцінку всіх компонентів методичної системи навчання, створення максимально сприятливих умов для розкриття і розвитку здібностей особи, що здобуває знання. Один із провідних напрямків гуманізації - впровадження особистісно зорієнтованого навчання, мета якого не тільки навчати й виховувати учня, а й формувати в ньому особистість. Такий підхід до навчального процесу передбачає індивідуалізацію, а отже, й диференціацію навчання, ефективним засобом якої за певної умови організації $\epsilon$ самостійна робота.

Одне з головних завдань сучасної освіти - навчити учнів самостійно працювати, оскільки темпи надходження наукової інформації надзвичайно зросли і практично кожній людині, яка хоче мати роботу та продуктивно працювати, необхідно увесь час поновлювати свої знання, а то й переучуватись, а це можливо лише за наявності сформованих умінь і навичок самостійної роботи. 